\title{
Differentiation and Exploration of Model MACP for HE VER 1.0 on Prototype Performance Measurement Application for Higher Education
}

\author{
R. Reza El Akbar ${ }^{1}$, Muhammad Adi Khairul Anshary ${ }^{1}$ and Dennis Hariadi ${ }^{2}$ \\ ${ }^{1}$ Lecture in Department of Informatics Engineering, Siliwangi University, Tasikmalaya 46115 - Indonesia \\ ${ }^{2}$ Student in Department of Informatics Engineering, Siliwangi University, Tasikmalaya 46115 - Indonesia
}

\begin{abstract}
Model MACP for HE ver.1. Is a model that describes how to perform measurement and monitoring performance for Higher Education. Based on a review of the research related to the model, there are several parts of the model component to develop in further research, so this research has four main objectives. The first objective is to differentiate the CSF (critical success factor) components in the previous model, the two key KPI (key performance indicators) exploration in the previous model, the three based on the previous objective, the new and more detailed model design. The final goal is the fourth designed prototype application for performance measurement in higher education, based on a new model created. The method used is explorative research method and application design using prototype method. The results of this study are first, forming a more detailed new model for measurement and monitoring of performance in higher education, differentiation and exploration of the Model MACP for HE Ver.1. The second result compiles a dictionary of college performance measurement by re-evaluating the existing indicators. The third result is the design of prototype application of performance measurement in higher education.
\end{abstract}

\section{Introduction}

Measurement of performance in every organization or institution is required, both governmental and private institutions. This is because the performance measurement related to the quality of the institution [1]. The quality of an institution that is measured both quantitatively and qualitatively based on supporting information, easy to describe and explain its achievement, will be beneficial to the institution in establishing, managing and monitoring its performance targets and achievement strategies. No exception for higher education institutions should always be consistent in maintaining and improving the quality of graduates.

Various ways taken, one of which measures each performance on the parts of the process that exist in the institution, to then carried out monitoring, evaluation and improvement.

Based on the preliminary literature review, a performance measurement model found that simultaneously monitored performance. The model is Model Measurement and Controlling Performance for Higher Education Ver. 1.0 (MACP for HE Ver. 1.0) [2]. The model shows the existence of input transformation process and output in activities of higher education.

In the model has not shown in detail each of the translation from CSF to KPI. Further exploration for the model is required. In addition, the translation of each KPI need to be revised and adjusted as required. The description of the background is one reason why the study was conduct.

There are four main objectives of this study. First, perform Differentiation and Exploration of CSF components on references research models. The two conduct KPI Exploration on each CSF. Third design a new model that more detail and the last make prototype application of college performance measurement.

\section{Experimental Details}

The sequence of this research step follows four stages of research, which described as follows:

- Differentiation of CSF components by reviewing the related literature through literature study.

- The exploration of KPI components by literature search. Adjustment process is the next stage to understand the condition of the environment, especially the higher education environment in Indonesia.

- The design of the new model after the Differentiation and Exploration stage is completed. This stage adds and completes the model that becomes the reference model MACP for HE Ver. 1.0, so that model of Version 2 formed. At this stage the first step is to evaluate

\footnotetext{
Corresponding author: reza@unsil.ac.id
} 
the reference model, then modify the old model to produce a new model.

- The prototype design is the final step in this research to get an overview of the application. Prototype method consists of five stages, at this stage presented in this journal only the results of the design or modelling stage in the form of display interface application.

\section{Results and Discussions}

\subsection{Differentiation of CSF components}

At this stage, a review of each component of the CSF (Critical Success Factor) model is modelled base. In this section, CSF produced a new product. CSF defined as all products of research and other useful works and bias directly used in the community. This section includes research products, books, intellectual property rights and more [3]. Some CSF components incorporated in this section, such as CSF information in the input and output areas combined.

\subsection{Exploration of KPI components}

In this section the translation of each KPI (Key Performance Indicator) becomes more detailed, each KPI is grouped based on three areas namely input area, process area and output area.

All the elaborations in this section plotted on the KPI tables presented after the depiction of the new model presented at the design stage and the creation of a new model. In general, the KPI in this section divided into five parts of KPI namely:

1. KPI derived from CSF Area Input and given the symbol with I-KPI (KPI for Input Area).

2. KPI derived from CSF Process Area. In this section divided into three parts:

a. KPI derived from CSF Information Flow and symbolized with P-KPI Information (KPI for Process Area Information);

b. KPI derived from CSF Transformation Process and symbolized with P-KPI Transformation (KPI for Process Area Transformation);

c. KPI derived from CSF Flow of Funds and given a symbol with P-KPI Flow of Funds (KPI for Process Flow Area Fund)

3. KPI derived from CSF Area Output and symbolized with O-KPI (KPI for Output Area).

\subsection{New Model Creation}

The old model that became the reference in this study, as shown in Figure 1 MACP Model for HE Ver. 1.0 describes the relationship between input, process and output.



Fig. 1. Model MACP for HE ver 1.0 [2]

Based on the review and discussion by reviewing some parts of the model then there are some models revision or improvement. The following descriptions and improvements made, as a basis for the creation of new models.

1. The input, process and output reinforced as an effort to separate the areas.

2. Incoming and outgoing information on the model merged into a part of the process area

3. Based on the previous study that is differentiation and exploration, both CSF and KPI there is a new

KPI that is CSF product is new part of Area Output. Based on the previous descriptions, a new model with the name of MACP for HE Ver. 0.2 as shown in Figure 2 below. The model shows that the area for Performance Measurement Model of Higher Education divided into three main areas namely Input Area, Process Area and Output Area.

Information and Financial or fund flows are in the process area and each has a KPI. There are five CSF groups: CSF in Input group / area, CSF group / process area of transformations, CSF group / Information process area, CSF group / financial process area, last CSF Group / output area. 




Fig. 2 Model MACP for HE ver 2.0

Based on the model then the following described some of the KPI to be calculated. The following presented in the form of a table, to facilitate which parts will be measured.

Table 1. KPI for CSF in Input Area

\begin{tabular}{|c|c|c|}
\hline No. & $\overline{\mathrm{CSF}}$ & $\overline{\text { KPI }}$ \\
\hline 1 & $\begin{array}{l}\text { College } \\
\text { student }\end{array}$ & $\begin{array}{l}\text { Number of scholarships available } \\
\text { [4], Ratio of prospective students } \\
\text { participating in selection and } \\
\text { capacity [5] }\end{array}$ \\
\hline 2 & $\begin{array}{l}\text { Facilities and } \\
\text { infrastructure }\end{array}$ & $\begin{array}{l}\text { Number of Rooms available [4], } \\
\text { Condition of learning support } \\
\text { facilities [4], Number of library } \\
\text { materials and other equipment [6] }\end{array}$ \\
\hline 3 & $\begin{array}{l}\text { Organizations } \\
\text { and Leadership }\end{array}$ & $\begin{array}{l}\text { Periodic evaluation of roles and } \\
\text { functions of organization and } \\
\text { leadership [7] }\end{array}$ \\
\hline 4 & Lecturer & $\begin{array}{l}\text { Level of education, academic } \\
\text { position, certification, } \\
\text { achievement level of learning } \\
\text { evaluation result by lecturer [4] }\end{array}$ \\
\hline 5 & Employee & Employee competency score [8], \\
\hline 6 & Cooperation & $\begin{array}{l}\text { Number of cooperation grouped } \\
\text { by level }[9]\end{array}$ \\
\hline
\end{tabular}

Table 2. KPIs for CSFs in the Information Process Area

\begin{tabular}{|c|l|l|}
\hline No. & \multicolumn{1}{|c|}{ CSF } & \multicolumn{1}{c|}{ KPI } \\
\hline 1 & Information & $\begin{array}{l}\text { Total availability of } \\
\text { information system all } \\
\text { activities of each unit [10] }\end{array}$ \\
\hline
\end{tabular}

Table 3. KPIs for CSF in the Transformation Process Area

\begin{tabular}{|c|c|c|}
\hline No. & CSF & KPI \\
\hline 1 & Procedure Guardian & $\begin{array}{l}\text { The level of satisfaction } \\
\text { of the leadership of each } \\
\text { unit [11] }\end{array}$ \\
\hline 2 & Management System & $\begin{array}{l}\text { Number of systems } \\
\text { available for the } \\
\text { management of each unit } \\
\text { [11] }\end{array}$ \\
\hline 3 & Quality assurance & $\begin{array}{l}\text { Quality standard report } \\
\text { [11] }\end{array}$ \\
\hline 4 & Learning Curriculum & $\begin{array}{l}\text { Percentage of curriculum } \\
\text { completeness }[11]\end{array}$ \\
\hline 5 & $\begin{array}{l}\text { Academics } \\
\text { Atmosphere }\end{array}$ & $\begin{array}{l}\text { Presentation of comfort } \\
\text { academic atmosphere [11] }\end{array}$ \\
\hline 6 & $\begin{array}{l}\text { Students } \\
\text { Achievement }\end{array}$ & $\begin{array}{l}\text { Total student achievement } \\
\text { [11] }\end{array}$ \\
\hline 7 & Learning objectives & $\begin{array}{l}\text { Percentage of learning } \\
\text { achievement [11] }\end{array}$ \\
\hline 8 & Students Assessment & $\begin{array}{l}\text { Average student score } \\
{[11]}\end{array}$ \\
\hline
\end{tabular}

Table 4. KPIs for CSFs in the Financial Process Area

\begin{tabular}{|c|l|l|}
\hline No. & \multicolumn{1}{|c|}{ CSF } & \multicolumn{1}{c|}{ KPI } \\
\hline 1 & Financial & $\begin{array}{l}\text { Financial statements for } \\
\text { cash inflows and outflows } \\
{[11]}\end{array}$ \\
\hline
\end{tabular}

Table 5. KPI for CSF in Output Area

\begin{tabular}{|c|c|c|}
\hline No. & CSF & KPI \\
\hline 1 & Graduate & $\begin{array}{l}\text { Length of waiting period, average } \\
\text { IPK [10], [1 } 1]\end{array}$ \\
\hline 2 & Graduates & Work suitability, [12] \\
\hline 3 & Research & $\begin{array}{l}\text { Number of lecturers' research, } \\
\text { student participation [13] }\end{array}$ \\
\hline 4 & Devotion & $\begin{array}{l}\text { Total devotion of lecturers, } \\
\text { student participation [14] }\end{array}$ \\
\hline 5 & Product & $\begin{array}{l}\text { Number of commercial products } \\
\text { [13] }\end{array}$ \\
\hline
\end{tabular}

\subsection{Prototype Design Results}

Based on the results of the application design obtained interface as shown below:

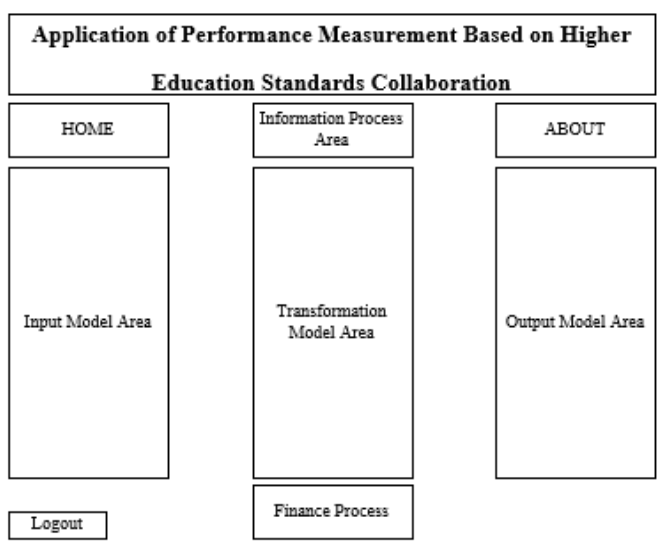

Fig. 3 User Interface Applications 


\section{Conclusion}

After the research steps consisting of four research steps, the Measurement and Controlling Performance for Higher Educations (MACP for HE Ver. 2.0) model has successfully constructed from the previous version of the model. The details of each KPI can be trace further through the performance measurement table presented in this journal.

The prototype application design has been successfully created and presented, but has not been tested or tested thoroughly on prototype results of performance measurement applications in this college.

Further research needs conducting laboratory-scale trials. Research related to this topic that needs to be developed and research is the application of monitoring performance appraisal results and applications to evaluate the performance of universities.

\section{Acknowledgments}

The authors would like to thank to the Ministry of Technology, Research, Higher Educations of the Republic Indonesia for funding this project. Especially to LPPM (Lembaga Penelitian dan Pengabdian Masyarakat) Siliwangi University, to give authors funding of research innovation for the second year.

\section{References}

1. S. Luis, and P.A. Biromo, Step by Step in Cascading Balanced Scorecard, Jakarta: PT Gramedia Pustaka Utama (2008)

2. Akbar, R. Reza El; Anshary, Muhammad Adi Khairul., Volume 23, Number 3, pp. 2354-2357(4), (2017)
3. Panduan penelitian SIMLITABMAS (2017)

4. SPM-ITB, Standar Mutu Akademik dan Instrumen Pengukuran, 4 (2015)

5. F.C. Saputro, W. Anggraeni, A. Mukhlason, Pembuatan Dashboard Berbasis Web Sebagai Sarana Evaluasi Diri Berkala untuk Persiapan Penilaian Akreditasi Berdasarkan Standar Badan Akreditasi Nasional Perguruan Tinggi, 1 (2012)

6. SPMI-UNDIP, Standar Sarana Dan Prasarana Sistem Penjaminan Mutu Internal Universitas Diponegoro, (2011)

7. A. Junaidi, Standar Nasional Pendidikan Tinggi Permenristekdikti No. 44 Tahun 2015, (2016)

8. Yodhia Antariksa. KPI Bidang SDM,Marketing, IT Finance dan Produksi Universitas Airlangga, (2010)

9. H. Nur Fatima, Alimuddin, D. Said. Hubungan Antar key performance indicators (2013)

10. F.Cahyo Saputro, W. Anggraeni dan A. Mukhlason. Pembuatan Dashboard Berbasis Web Institut Teknologi Sepuluh Nopember (2012)

11. Badan Akreditasi Nasional-Perguruan Tinggi;Buku Ii Standar Dan Prosedur Akreditasi Program Studi Sarjana;2008;Jakarta, Indonesia.

12. Syahru Rahmayuda. Sistem Informasi Evaluasi Tracerstudy Untuk Pengukuran Key Performance Indicators Alumni Menggunakan Metode Fuzzy. Program Pascasarjana Universitas Diponogoro Semarang,(2013)

13. I Made Suartika, Perancangan Dan Implementasi Sistem Pengukuran Kinerja Dengan Metode Integrated Performance Measurement Systems (Studi Kasus: Jurusan Teknik Mesin Universitas Mataram)

14. Jurnal Teknik ITS Vol. 1, ISSN: 2301-9271 Jurusan Sistem Informasi, Fakultas Teknologi Informasi, Institut Teknologi Sepuluh Nopember (ITS), (2012) 